\title{
Pandoraea thiooxydans sp. nov., a facultatively chemolithotrophic, thiosulfate-oxidizing bacterium isolated from rhizosphere soils of sesame (Sesamum indicum L.)
}

Correspondence Tong Min Sa tomsa@chungbuk.ac.kr
Rangasamy Anandham, ${ }^{1,2}$ Pandiyan Indiragandhi, ${ }^{2,3}$ Soon Wo Kwon, ${ }^{4}$
Tong Min Sa, ${ }^{2}$ Che Ok Jeon, ${ }^{5}$ Yong Ki Kim ${ }^{1}$ and Hyeong Jin Jee ${ }^{1}$

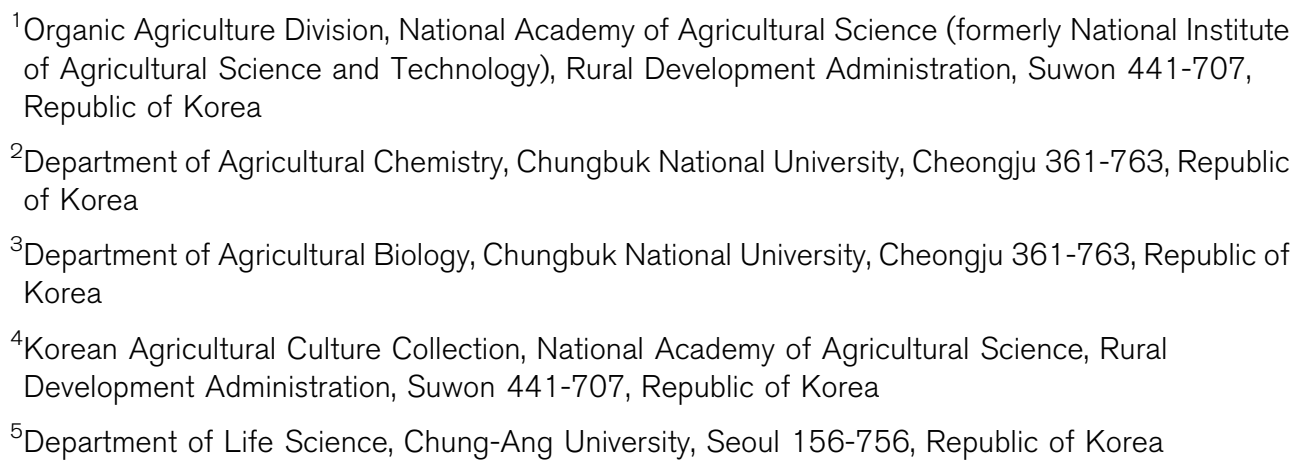

A facultatively chemolithoautotrophic, thiosulfate-oxidizing, Gram-negative, aerobic, motile, rodshaped bacterial strain, designated $\mathrm{ATSB} 16^{\top}$, was isolated from rhizosphere soils of sesame (Sesamum indicum L.). 16S rRNA gene sequence analysis demonstrated that this strain was closely related to Pandoraea pnomenusa LMG $18087^{\top}$ (96.7\% similarity), P. pulmonicola LMG $18016^{\top}(96.5 \%)$, P. apista LMG $16407^{\top}(96.2 \%)$, P. norimbergensis LMG $18379^{\top}(96.1 \%)$ and P. sputorum LMG $18819^{\top}$ (96.0\%). Strain ATSB $16^{\top}$ shared $96.0-96.4 \%$ sequence similarity with four unnamed genomospecies of Pandoraea. The major cellular fatty acids of the strain ATSB $16{ }^{\top}$ were $\mathrm{C}_{17: 0}$ cyclo $(33.0 \%)$ and $\mathrm{C}_{16: 0}(30.6 \%)$. Q-8 was the predominant respiratory quinone. The major polar lipids were phosphatidylmethylethanolamine, diphosphatidylglycerol, phosphatidylethanolamine and two unidentified aminophospholipids. Hydroxyputrescine and putrescine were the predominant polyamines. The genomic DNA G+C content of the strain was $64.0 \mathrm{~mol} \%$. On the basis of the results obtained from this study, strain ATSB16 ${ }^{\top}$ represents a novel species of the genus Pandoraea, for which the name Pandoraea thiooxydans sp. nov. is proposed. The type strain is ATSB $16^{\top}\left(=\right.$ KACC $12757^{\top}=$ LMG $\left.24779^{\top}\right)$.
Currently, the genus Pandoraea consists of five species, namely Pandoraea pnomenusa, $P$. pulmonicola, $P$. apista, $P$. norimbergensis and $P$. sputorum, and four genomospecies (Coenye et al., 2000; Daneshvar et al., 2001). During a study of thiosulfate-oxidizing bacterial populations in sesame rhizosphere soils, one of the isolates, strain ATSB $16^{\mathrm{T}}$, was subjected to phenotypic, genotypic and chemotaxonomic investigations in order to determine its taxonomic position.

Rhizosphere soil samples were collected from sesame (Sesamum indicum L.) cultivated in fields in Jung ha-dong $\left(35^{\circ} 10-17^{\prime} \mathrm{N} 128^{\circ} 49-56^{\prime} \mathrm{E}\right)$, Republic of Korea.

The GenBank/EMBL/DDBJ accession number for the $16 \mathrm{~S}$ rRNA gene sequence of strain $\mathrm{ATSB} 6^{\top}$ is EF397578.
Rhizosphere soil (soil still attached to the roots after gentle shaking) and fine roots (approximately $1 \mathrm{~cm}$ in length) from five plants were pooled into one sample, homogenized by thorough hand-mixing and used for enrichment isolation. Each rhizosphere soil sample (10 g) was added to $100 \mathrm{ml}$ liquid mineral salts thiosulfate (MST) medium (Mukhopadhyaya et al., 2000) and incubated in a rotary shaker at $30^{\circ} \mathrm{C}$, in the dark to avoid any growth of phototrophic bacteria, until the colour of the indicator in the medium, bromcresol purple, changed to yellow. To isolate pure cultures, 10 -fold dilutions $\left(10^{2}-10^{6}\right)$ were made with sterile deionized water and $0.2 \mathrm{ml}$ aliquots were spread with sterile glass sticks on MST agar. Colonies that developed a yellow halo against a purple background, indicative of the production of sulfuric acid resulting from 
the oxidation of thiosulfate, were selected, streaked on solid MST medium and subcultured until one unique type of colony was observed. Strain ATSB16 ${ }^{\mathrm{T}}$ was one of the isolates that could be distinguished in terms of colony morphology and rate and extent of acid production in MST medium. The strain was maintained on MST agar and subcultured every week.

The 16S rRNA gene sequence of strain $\operatorname{ATSB} 6^{\mathrm{T}}$ was determined by PCR amplification and direct sequencing as described previously (Anandham et al. 2008a, b). A phylogenetic analysis was performed with multiple sequence alignments using CLUSTAL $\mathrm{W}$ version 1.8 (Thompson et al., 1994). Phylogenetic trees were constructed with neighbour-joining (Saitou \& Nei, 1987), maximum-parsimony (Fitch, 1971) and maximum-likelihood (Felsenstein, 1981) methods using the program MEGA3 (Kumar et al., 2004) and bootstrap values based on 1000 replications were calculated (Felsenstein, 1985).

Gram-staining was performed by using a Gram-staining kit (Difco) and qualitative tests for catalase and oxidase activities were performed using catalase and oxidase strips (Difco), according to the manufacturer's instructions. Cell morphology was observed under transmission and scanning electron microscopes. Growth under heterotrophic conditions was monitored for 10 days at $30{ }^{\circ} \mathrm{C}$ in mineral salts medium without thiosulfate with several organic compounds (sodium succinate, sodium acetate, sodium citrate, D-glucose, D-fructose, $\alpha$-lactose, D-mannose, sucrose, xylose, glycerol, mannitol, L-glutamic acid, sorbitol, malic acid, L-glutamine, L-cysteine, yeast extract, methanol and starch; $0.2 \%, \mathrm{w} / \mathrm{v}$, for each carbohydrate and $0.1 \%$, w/ $v$, for each organic acid, sugar alcohol and yeast extract). Chemo-organotrophic growth was tested on Luria-Bertani agar, nutrient agar, tryptic soy agar (TSA) and R2A agar (all from Difco). The ability to oxidize and grow on different reduced sulfur compounds was tested by using mineral salts medium supplemented with one of the following compounds: thiosulfate $(20 \mathrm{mM})$, tetrathionate $(10 \mathrm{mM})$, sulfite $(3 \mathrm{mM}$ in $50 \mathrm{mM}$ EDTA to prevent autooxidation), thiocyanate $(2 \mathrm{mM})$ and elemental sulfur $(0.1 \%, w / v)$. Mixotrophic growth (i.e., concurrent utilization of organic and inorganic substrates) was examined in mixotrophic medium as described by Anandham et al. (2007). The $\mathrm{pH}$ range for growth was determined in R2A broth from $\mathrm{pH} 4.0$ to 10.0, in increments of $0.5 \mathrm{pH}$ units. All of the basic physiological and biochemical tests were performed at $30{ }^{\circ} \mathrm{C}$ according to Gerhardt et al. (1994). Growth at various $\mathrm{NaCl}$ concentrations (1-7\%) and temperatures $\left(4-50{ }^{\circ} \mathrm{C}\right)$ was investigated in $\mathrm{R} 2 \mathrm{~A}$ broth. Physiological and biochemical properties were further determined with the API ZYM, API 20NE and ID 32 GN systems (bioMérieux), according to the manufacturer's instructions.

For the analysis of the cellular fatty acids, cells grown on TSA plates at $30{ }^{\circ} \mathrm{C}$ for $48 \mathrm{~h}$ were used. Fatty acid methyl esters were extracted and prepared by using the standard protocol of the Microbial Identification System (Microbial ID). The $\mathrm{G}+\mathrm{C}$ content was determined by HPLC analysis of deoxyribonucleosides as described by Mesbah et al. (1989) using a reversed-phased column (Supelcosil LC-18S; Supelco). Polar lipids were extracted and analysed by two-dimensional TLC according to Minnikin et al. (1984). Polyamines and isoprenoid quinones were extracted and analysed in HPLC, as described by Busse et al. (1997) and Groth et al. (1996), respectively.

An almost-complete 16S rRNA gene sequence of strain ATSB $16^{\mathrm{T}}$ was obtained (1410 bp). Preliminary sequence comparisons with $16 \mathrm{~S}$ rRNA gene sequences retrieved from the GenBank database indicated that strain ATSB $16^{\mathrm{T}}$ belonged to the family Burkholderiaceae of the Betaproteobacteria. 16S rRNA gene sequence analysis revealed that strain $\mathrm{ATSB}^{\mathrm{T}}{ }^{\mathrm{T}}$ is closely related to $P$. pnomenusa LMG $18087^{\mathrm{T}}$ (96.7\% similarity), P. pulmonicola LMG $18016^{\mathrm{T}}$ (96.5\%), P. apista LMG $16407^{\mathrm{T}}(96.2 \%)$, P. norimbergensis LMG $18379^{\mathrm{T}}(96.1 \%)$, P. sputorum LMG $18819^{\mathrm{T}}(96.0 \%)$, Pandoraea genomospecies $1 \mathrm{R}-5199$ and Pandoraea genomospecies 2 CDC G5084 (96.0\%), Pandoraea genomospecies 3 CDC G9805 (96.2\%) and Pandoraea genomospecies 4 CDC H652 (96.4\%). The overall topologies of the maximum-parsimony and maximum-likelihood trees were similar to that of the neighbour-joining tree. The phylogenetic analysis revealed that strain ATSB $16^{\mathrm{T}}$ formed a line of descent that was separate from the genus Pandoraea, which was supported by a high bootstrap value (Fig. 1).

After 2 days on R2A, colonies of strain $\mathrm{ATSB}^{\mathrm{T}}{ }^{\mathrm{T}}$ were white, circular and convex with clear margins. Cells were Gram-negative, aerobic, rod-shaped and motile by means of a single polar flagellum (Fig. 2). The strain grew chemolithoautotrophically on reduced sulfur compounds such as thiosulfate, sulfur and sulfite and chemo-organoheterotrophically on several single carbon sources. The strain did not require yeast extract or vitamins under either of these conditions. Both strain ATSB $16^{\mathrm{T}}$ and P. norimbergensis DSM $11628^{\mathrm{T}}$ exhibited mixotrophic growth in mineral salts medium containing $20 \mathrm{mM}$ thiosulfate plus $20 \mathrm{mM}$ sodium acetate or glucose. $P$. norimbergensis DSM $11628^{\mathrm{T}}$ could also grow chemolithoautotrophically with thiosulfate (Table 1). Mixotrophic growth may be metabolically advantageous, because low concentrations of sulfur compounds can limit growth and so the use of organic carbon for biomass synthesis, or even the cooxidation of sulfur compounds with organic substrates, may ensure the better survival and growth of sulfuroxidizing bacteria in the rhizosphere (Anandham et al., 2007). In a previous study, we reported that strain ATSB $16^{\mathrm{T}}$ could use the tetrathionate-intermediate (S4-I) pathway for thiosulfate oxidation and that extracellular accumulation of elemental sulfur was observed during thiosulfate oxidation (Anandham et al., 2008b). Strain ATSB $16^{\mathrm{T}}$ was able to fix nitrogen in nitrogen-free $\mathrm{NFb}$ medium but did not yield a positive amplicon with nifHspecific primers (Anandham et al., 2008a). 


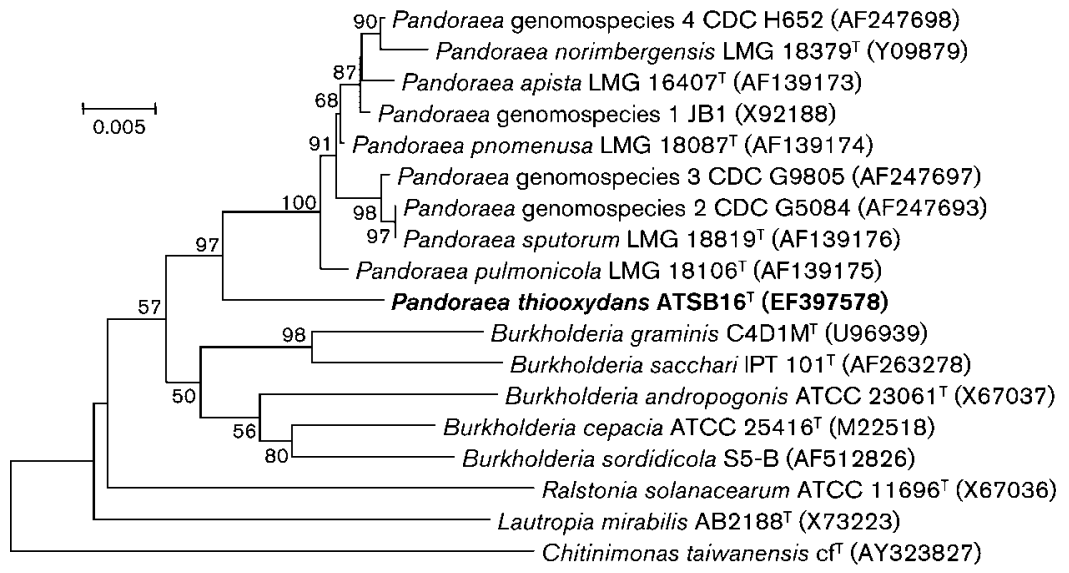

Fig. 1. Neighbour-joining phylogenetic tree based on 16S rRNA gene sequences showing the position of strain ATSB $16^{\top}$. Bootstrap values $(>50 \%)$ based on 1000 replications are shown at branch nodes. Bar, 0.005 substitutions per nucleotide position.
In the present study, lipase (C14), valine arylamidase, cystine arylamidase, trypsin, $\alpha$-chymotrypsin, $\alpha$ - and $\beta$ galactosidases, $\beta$-glucuronidase, $\alpha$ - and $\beta$-glucosidases, $N$ acetyl- $\beta$-glucosaminidase, $\alpha$-mannosidase and $\alpha$-fucosidase were not found in strain ATSB $16^{\mathrm{T}}$ or any of the recognized Pandoraea species. The absence of aesculin and gelatin hydrolysis and $\mathrm{N}$-acetylglucosamine assimilation and the presence of leucine arylamidase activity and utilization of

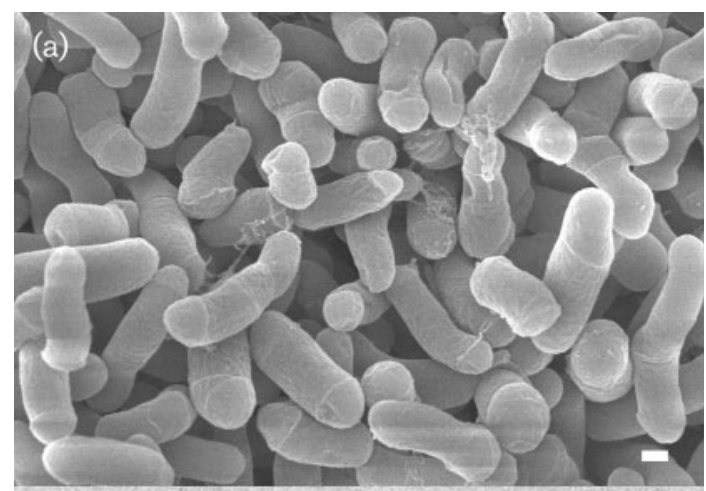

(b)

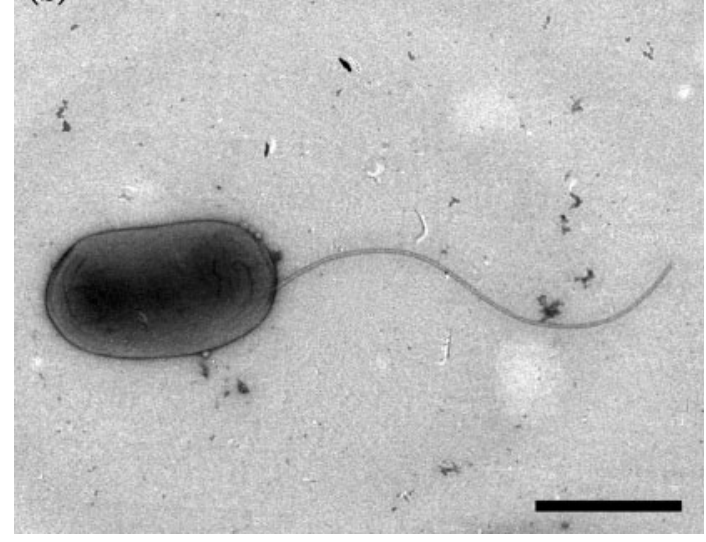

Fig. 2. Scanning (a) and transmission (b) electron microscope images of cells of strain ATSB16 ${ }^{\top}$. Bars, $200 \mathrm{~nm}(\mathrm{a})$ and $1 \mu \mathrm{m}(\mathrm{b})$. phenylacetic acid were observed in strain ATSB $16^{\mathrm{T}}$ and all of the recognized Pandoraea species. These results are in good agreement with previous results (Coenye et al., 2000). However, Coenye et al. (2000) reported the absence of assimilation of substrates such as L-arabinose and Dmannitol and the presence of alkaline phosphatase activity in Pandoraea species, for which the present study observed discrepancies. Such laboratory-to-laboratory discrepancies show the importance of obtaining and testing valid reference strains to verify their reactions with in-house procedures (Daneshvar et al., 2001). Strain ATSB16 ${ }^{\mathrm{T}}$ can be differentiated from other Pandoraea species on the basis of its ability to assimilate D-mannose, maltose, L-rhamnose and L-fucose and inability to assimilate capric acid. The characteristics that differentiate strain ATSB $16^{\mathrm{T}}$ from other recognized Pandoraea species are shown in Table 1.

The fatty acid analysis revealed that strain ATSB $16^{\mathrm{T}}$ had a similar fatty acid profile to those of other Pandoraea species. However, it can be differentiated from other Pandoraea species on the basis of large amounts of $\mathrm{C}_{16: 0}$ $(30.6 \%)$ and $\mathrm{C}_{17: 0}$ cyclo $(33.0 \%)$ and a small amount of $\mathrm{C}_{18: 1} \omega 7 c(3.0 \%)$ (Table 2$)$. The major quinone in strain ATSB $16^{\mathrm{T}}$ was ubiquinone $8(\mathrm{Q}-8)$ and the predominant polyamines were 2 -hydroxyputrescine and putrescine. The DNA G + C content of strain ATSB16 ${ }^{\mathrm{T}}$ was $64.0 \mathrm{~mol} \%$, which is within the range reported for other Pandoraea species (61.2-64.3 mol\%) (Coenye et al., 2000). Strain ${\text { ATSB } 16^{\mathrm{T}}}$ contained the polar lipids phosphatidylmethylethanolamine, diphosphatidylglycerol, phosphatidylethanolamine and unidentified aminophospholipids (Fig. 3).

The genotypic, phenotypic and chemotaxonomic data obtained from this study clearly demonstrate that strain ATSB $16^{\mathrm{T}}$ represents a novel Pandoraea species, for which we propose the name Pandoraea thiooxydans sp. nov.

\section{Description of Pandoraea thiooxydans sp. nov.}

Pandoraea thiooxydans (thi.o.ox'y.dans. Gr. n. theion sulfur; N.L. v. oxydo to make acid, oxidize; N.L. part. adj. thiooxydans oxidizing sulfur). 
Table 1. Differential phenotypic and chemotaxonomic characteristics of strain $\mathrm{ATSB}^{\mathrm{T}} \mathrm{6}^{\mathrm{T}}$ and type strains of the genus Pandoraea

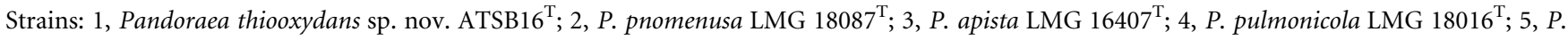
sputorum LMG $18819^{\mathrm{T}}$; 6, P. norimbergensis DSM $11628^{\mathrm{T}}$. Data were obtained in this study unless indicated. All strains were positive for assimilation of malic acid, trisodium citrate, phenylacetic acid, sodium acetate, L-alanine, valeric acid, 3-hydroxybutyric acid and L-proline and activities of leucine arylamidase and naphthol-AS-BI-phosphohydrolase. All strains were negative for indole production, hydrolysis of aesculin and gelatin, assimilation of $\mathrm{N}$-acetylglucosamine, D-ribose, inositol, sucrose, itaconic acid, potassium 5-ketogluconate, potassium 2-ketogluconate, salicin and melibiose and activities of lipase (C14), valine arylamidase, cystine arylamidase, trypsin, $\alpha$-chymotrypsin, $\alpha$ - and $\beta$-galactosidases, $\beta$ glucuronidase, $\alpha$ - and $\beta$-glucosidases, $N$-acetyl- $\beta$-glucosaminidase, $\alpha$-mannosidase and $\alpha$-fucosidase. + , Positive; - , negative; w, weakly positive.

\begin{tabular}{|c|c|c|c|c|c|c|}
\hline Characteristic & 1 & 2 & 3 & 4 & 5 & 6 \\
\hline Catalase & - & + & + & + & + & + \\
\hline Growth with $4.5 \% \mathrm{NaCl}$ & + & - & - & - & - & - \\
\hline Chemolithoautotrophic oxidation of thiosulfate & + & - & - & - & - & + \\
\hline Mixotrophic growth with thiosulfate & + & - & - & - & - & + \\
\hline \multicolumn{7}{|l|}{ Assimilation of: } \\
\hline L-Fucose & + & - & - & - & - & - \\
\hline D-Glucose & + & $\mathrm{w}$ & + & + & - & + \\
\hline D-Mannose & + & - & - & - & - & - \\
\hline D-Mannitol & + & - & - & - & + & - \\
\hline Maltose & + & - & - & - & - & - \\
\hline L-Rhamnose & + & - & - & - & - & - \\
\hline Capric acid & - & + & + & + & + & + \\
\hline 3-Hydroxybenzoic acid & - & $\mathrm{w}$ & + & + & + & + \\
\hline 4-Hydroxybenzoic acid & - & $\mathrm{w}$ & + & + & + & + \\
\hline Lactic acid & + & + & + & + & - & $\mathrm{w}$ \\
\hline Propionic acid & + & $\mathrm{w}$ & + & + & + & + \\
\hline Suberic acid & $\mathrm{w}$ & + & - & - & - & - \\
\hline Glycogen & $\mathrm{w}$ & - & - & - & - & - \\
\hline L-Serine & + & + & + & + & + & $\mathrm{w}$ \\
\hline \multicolumn{7}{|l|}{ Enzyme activity } \\
\hline Esterase (C4) & $\mathrm{w}$ & + & + & + & + & + \\
\hline Esterase lipase (C8) & - & - & - & - & - & $\mathrm{w}$ \\
\hline
\end{tabular}

${ }^{\star}$ Result with mineral salts medium amended with $20 \mathrm{mM}$ thiosulfate plus $20 \mathrm{mM}$ sodium acetate or glucose.

$\dagger$ Taken from Coenye et al. (2000).

Displays the following properties in addition to those given in Table 1. After 2 days on R2A, colonies are white, circular and convex with clear margins. Cells are Gram-negative, aerobic, rod-shaped and motile by means of a single polar flagellum, $0.5-0.7 \mu \mathrm{m}$ wide and 1.2-4.5 $\mu \mathrm{m}$ long. Negative for catalase. Positive for oxidase and urease. Reduces nitrate and hydrolyses Tween 80 . Grows at $4-42{ }^{\circ} \mathrm{C}$ (optimum $30^{\circ} \mathrm{C}$ ) and $\mathrm{pH} \mathrm{4.0-10.0} \mathrm{(optimum} \mathrm{pH}$ 7.0). Produces acid in $\mathrm{O} / \mathrm{F}$ glucose medium and grows with $5 \%$ $\mathrm{NaCl}$. Sensitive to ampicillin, kanamycin, chloramphenicol and trimethoprim and resistant to nalidixic acid. Grows chemolithoautotrophically with thiosulfate, tetrathionate, sulfur and sulfite but not with thiocyanate. Elemental sulfur is deposited extracellularly during growth on media containing thiosulfate. Yeast extract or vitamins are not required for growth. Grows chemo-organoheterotrophically on tryptic soy agar, Luria-Bertani agar, nutrient agar and cetrimide agar. Assimilates D-mannose, maltose, Lrhamnose and L-fucose; does not assimilate capric acid. The predominant polar lipids are phosphatidylmethylethanolamine, diphosphatidylglycerol, phosphatidylethanolamine and unidentified aminophospholipids. The 
Table 2. Cellular fatty acid compositions of strain ATSB $16^{\top}$ and type strains of the genus Pandoraea

Strains: 1 , Pandoraea thiooxydans sp. nov. ATSB $16^{\mathrm{T}} ; 2$, P. pnomenusa LMG $18087^{\mathrm{T}}$; 3, P. apista LMG $16407^{\mathrm{T}}$; 4, P. pulmonicola LMG $18016^{\mathrm{T}}$; 5, P. sputorum LMG $18819^{\mathrm{T}}$; 6, P. norimbergensis DSM $11628^{\mathrm{T}}$. Data were obtained in this study. Cells were harvested after growth on TSA for 2 days at $30{ }^{\circ} \mathrm{C}$. ECL, Equivalent chain-length; tr, trace (less than $0.5 \%$ ).

\begin{tabular}{|c|c|c|c|c|c|c|}
\hline Fatty acids (\%) & 1 & 2 & 3 & 4 & 5 & 6 \\
\hline $\mathrm{C}_{10: 0}$ & $\operatorname{tr}$ & - & $\operatorname{tr}$ & $\operatorname{tr}$ & $\operatorname{tr}$ & $\operatorname{tr}$ \\
\hline $\mathrm{C}_{12: 0}$ & 3.5 & 2.1 & 2.2 & 3.1 & 3.0 & 2.4 \\
\hline $\mathrm{C}_{12: 0} 2-\mathrm{OH}$ & - & $\operatorname{tr}$ & $\operatorname{tr}$ & $\operatorname{tr}$ & $\operatorname{tr}$ & $\operatorname{tr}$ \\
\hline $\mathrm{C}_{12: 0} 3-\mathrm{OH}$ & $\operatorname{tr}$ & - & - & - & - & - \\
\hline $\mathrm{C}_{13: 0}$ & $\operatorname{tr}$ & - & - & - & - & - \\
\hline $\mathrm{C}_{13: 1}$ AT $12-13$ & $\operatorname{tr}$ & $\operatorname{tr}$ & $\operatorname{tr}$ & $\operatorname{tr}$ & $\operatorname{tr}$ & $\operatorname{tr}$ \\
\hline $\mathrm{C}_{14: 0}$ & 0.8 & 0.7 & $\operatorname{tr}$ & $\operatorname{tr}$ & $\operatorname{tr}$ & $\operatorname{tr}$ \\
\hline iso- $\mathrm{C}_{14: 0} 3-\mathrm{OH}$ & $\operatorname{tr}$ & - & - & - & - & - \\
\hline $\mathrm{C}_{14: 1} \omega 5 c$ & - & - & $\operatorname{tr}$ & - & - & - \\
\hline $\mathrm{C}_{15: 0} 3-\mathrm{OH}$ & $\operatorname{tr}$ & - & - & - & - & - \\
\hline $\mathrm{C}_{15: 1} \omega 6 c$ & $\operatorname{tr}$ & - & - & - & $\operatorname{tr}$ & $\operatorname{tr}$ \\
\hline $\mathrm{C}_{16: 0}$ & 30.6 & 24.7 & 24.8 & 20.3 & 18.9 & 17.8 \\
\hline $\mathrm{C}_{16: 0} 2-\mathrm{OH}$ & - & - & - & $\operatorname{tr}$ & $\operatorname{tr}$ & - \\
\hline $\mathrm{C}_{16: 0} 3-\mathrm{OH}$ & 1.7 & 4.7 & 5.9 & 5.8 & 6.4 & 4.7 \\
\hline $\mathrm{C}_{16: 1} 2-\mathrm{OH}$ & $\operatorname{tr}$ & - & - & $\operatorname{tr}$ & - & - \\
\hline$C_{16: 1} \omega 5 c$ & 0.8 & $\operatorname{tr}$ & - & - & $\operatorname{tr}$ & - \\
\hline iso- $\mathrm{C}_{16: 0}$ & 2.1 & - & - & - & - & - \\
\hline $\mathrm{C}_{17: 0}$ & 0.6 & $\operatorname{tr}$ & $\operatorname{tr}$ & $\operatorname{tr}$ & 0.7 & 0.6 \\
\hline $\mathrm{C}_{17: 0}$ cyclo & 33.0 & 10.7 & 9.9 & 8.0 & 13.3 & 4.5 \\
\hline iso- $\mathrm{C}_{17: 0} 3-\mathrm{OH}$ & - & - & - & $\operatorname{tr}$ & - & - \\
\hline$C_{18: 0}$ & $\operatorname{tr}$ & 1.4 & 1.1 & 1.4 & 1.5 & 2.5 \\
\hline $\mathrm{C}_{18: 1} 2-\mathrm{OH}$ & $\operatorname{tr}$ & $\operatorname{tr}$ & 0.5 & 0.5 & - & $\operatorname{tr}$ \\
\hline $\mathrm{C}_{18: 1} \omega 5 c$ & $\operatorname{tr}$ & $\operatorname{tr}$ & - & $\operatorname{tr}$ & $\operatorname{tr}$ & $\operatorname{tr}$ \\
\hline $\mathrm{C}_{18: 1} \omega 7 c$ & 3.0 & 23.7 & 24.1 & 25.3 & 28.1 & 35.5 \\
\hline $\mathrm{C}_{18: 1} \omega 7 c$ 11-methyl & - & $\operatorname{tr}$ & - & - & - & - \\
\hline $\mathrm{C}_{19: 0} \omega 8 c$ cyclo & 7.7 & 7.8 & 3.8 & 11.2 & - & 3.0 \\
\hline $\mathrm{C}_{19: 0}$ 10-methyl & - & - & - & $\operatorname{tr}$ & - & - \\
\hline$C_{20: 2} \omega 6,9 c$ & $\operatorname{tr}$ & - & - & $\operatorname{tr}$ & - & - \\
\hline ECL 13.957 & $\operatorname{tr}$ & - & - & - & - & - \\
\hline \multicolumn{7}{|l|}{ Summed features ${ }^{\star}$} \\
\hline 1 & $\operatorname{tr}$ & - & - & - & - & - \\
\hline 2 & 9.7 & 5.6 & 6.2 & 7.0 & 7.1 & 5.8 \\
\hline 3 & 3.4 & 16.2 & 20.1 & 14.8 & 19.1 & 21.4 \\
\hline 7 & 0.6 & - & - & - & - & - \\
\hline
\end{tabular}

*Summed features represent groups of fatty acids that cannot be separated by the Microbial Identification System. Summed feature 1 consisted of iso- $\mathrm{C}_{15: 1}$ I and/or $\mathrm{C}_{13: 0}$ 3-OH. Summed feature 2 consisted of one or more of $\mathrm{C}_{12: 0}$ aldehyde, an unknown fatty acid of ECL 10.928, iso- $\mathrm{C}_{16: 1} \mathrm{I}_{\text {and }} \mathrm{C}_{14: 0}$ 3-OH. Summed feature 3 consisted of $\mathrm{C}_{16: 1} \omega 7 c$ and/or iso- $\mathrm{C}_{15: 0}$ 2-OH. Summed feature 7 consisted of one or more of an unknown fatty acid of ECL 18.846, $\mathrm{C}_{19: 0} \omega 10 c$ cyclo and $\mathrm{C}_{19: 1} \omega 6 c$.

polyamine pattern contains 2-hydroxyputrescine and putrescine as the predominant compounds and the quinone system contains exclusively ubiquinone 8 (Q-8).

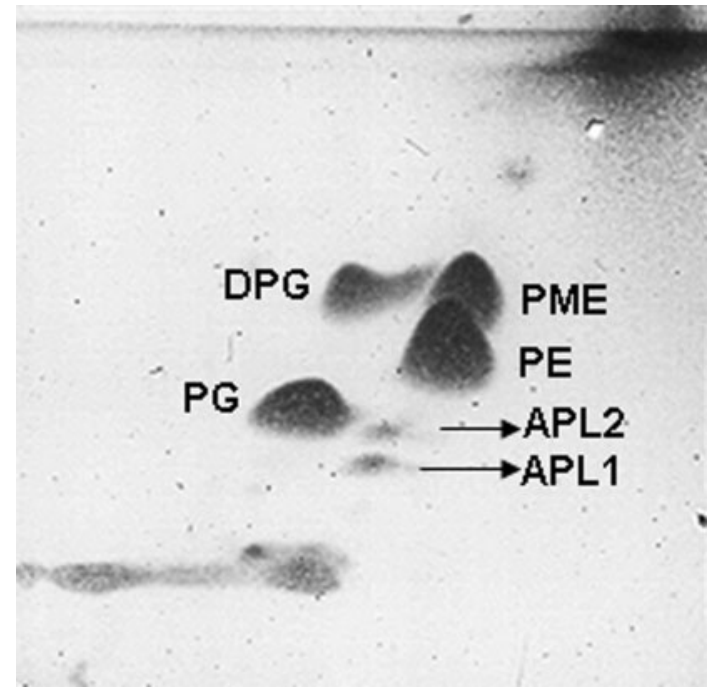

Fig. 3. Polar lipid pattern of strain $\mathrm{ATSB} 16^{\top}$ after separation by two-dimensional TLC. DPG, Diphosphatidylglycerol; PE, phosphatidylethanolamine; PG, phosphatidylglycerol; PME, phosphatidylmethylethanolamine; APL1 and APL2, unidentified aminophospholipids.

The major cellular fatty acids are $\mathrm{C}_{16: 0}$ and $\mathrm{C}_{17: 0}$ cyclo. The DNA G $+\mathrm{C}$ content of the type strain is $64.0 \mathrm{~mol} \%$.

The type strain, ATSB $16^{\mathrm{T}} \quad\left(=\mathrm{KACC} 12757^{\mathrm{T}}=\mathrm{LMG}\right.$ $\left.24779^{\mathrm{T}}\right)$, was isolated from rhizosphere soils of sesame in Jung ha-dong, Republic of Korea.

\section{Acknowledgements}

We thank Professor Dr Jean P. Euzéby for his assistance with etymology. R.A. and P. I. thank Korea Research Foundation Grant (KRF-2005-F00009) and Brain Korea (BK21). This study was partially supported by the National Academy of Agricultural Science, Rural Development Administration, Republic of Korea. Also, we thank anonymous referees and the editor for their valuable suggestions for improving the manuscript.

\section{References}

Anandham, R., Indira Gandhi, P., Kim, K. A., Yim, W. J., Madhaiyan, M., Saravanan, V. S., Chung, J. B. \& Sa, T. M. (2007). Thiosulfate oxidation and mixotrophic growth of Methylobacterium oryzae. Can J Microbiol 53, 869-876.

Anandham, R., Indira Gandhi, P., Madhaiyan, M. \& Sa, T. M. (2008a). Potential plant growth promoting traits and bioacidulation of rock phosphate by thiosulfate oxidizing bacteria isolated from crop plants. J Basic Microbiol 48, 439-447.

Anandham, R., Indira Gandhi, P., Madhaiyan, M., Ryu, H. Y., Jee, H. J. \& Sa, T. M. (2008b). Chemolithoautotrophic oxidation of thiosulfate and phylogenetic distribution of sulfur oxidation gene (soxB) in rhizobacteria isolated from crop plants. Res Microbiol 159, 579-589.

Busse, H. J., Bunka, S., Hensel, A. \& Lubitz, W. (1997). Discrimination of members of the family Pasteurellaceae based on polyamine patterns. Int J Syst Bacteriol 47, 698-708. 
Coenye, T., Falsen, E., Hoste, B., Ohlén, M., Goris, J., Govan, J. R. W., Gillis, M. \& Vandamme, P. (2000). Description of Pandoraea gen. nov. with Pandoraea apista sp. nov., Pandoraea pulmonicola sp. nov., Pandoraea pnomenusa sp. nov., Pandoraea sputorum sp. nov. and Pandoraea norimbergensis comb. nov. Int J Syst Evol Microbiol 50, 887-899.

Daneshvar, M. I., Hollis, D. G., Steigerwalt, A. G., Whitney, A. M., Spangler, L., Douglas, M. P., Jordan, J. G., MacGregor, J. P., Hill, B. C. \& other authors (2001). Assignment of CDC weak oxidizer group 2 (WO-2) to the genus Pandoraea and characterization of three new Pandoraea genomospecies. J Clin Microbiol 39, 1819-1826.

Felsenstein, J. (1981). Evolutionary trees from DNA sequences: a maximum likelihood approach. J Mol Evol 17, 368-376.

Felsenstein, J. (1985). Confidence limits on phylogenies: an approach using the bootstrap. Evolution 39, 783-791.

Fitch, W. M. (1971). Toward defining the course of evolution: minimum change for a specific tree topology. Syst Zool 20, 406-416.

Gerhardt, P., Murray, R. G. E., Wood, W. A. \& Krieg, N. R. (editors) (1994). Methods for General and Molecular Bacteriology. Washington, DC: American Society for Microbiology.

Groth, I., Schumann, P., Weiss, N., Martin, K. \& Rainey, F. A. (1996). Agrococcus jenensis gen. nov., sp. nov., a new genus of actinomycetes with diaminobutyric acid in the cell wall. Int J Syst Bacteriol 46, 234239.

Kumar, S., Tamura, K. \& Nei, M. (2004). MEGA3: integrated software for molecular evolutionary genetics analysis and sequence alignment. Brief Bioinform 5, 150-163.

Mesbah, M., Premachandran, U. \& Whitman, W. B. (1989). Precise measurement of the $\mathrm{G}+\mathrm{C}$ content of deoxyribonucleic acid by highperformance liquid chromatography. Int J Syst Bacteriol 39, 159-167.

Minnikin, D. E., O’Donnell, A. G., Goodfellow, M., Alderson, G., Athalye, M., Schaal, A. \& Parlett, J. H. (1984). An integrated procedure for the extraction of bacterial isoprenoid quinones and polar lipids. J Microbiol Methods 2, 233-241.

Mukhopadhyaya, P. N., Deb, C., Lahiri, C. \& Roy, P. (2000). A soxA gene encoding a diheme cytochrome $c$ and a sox locus, essential for sulfur oxidation in a new sulfur lithotrophic bacterium. $J$ Bacteriol 182, 4278-4287.

Saitou, N. \& Nei, M. (1987). The neighbor-joining method: a new method for reconstructing phylogenetic trees. Mol Biol Evol 4, 406-425.

Thompson, J. D., Higgins, D. G. \& Gibson, T. J. (1994). CLUSTAL W: improving the sensitivity of progressive multiple sequence alignment through sequence weighting, position-specific gap penalties and weight matrix choice. Nucleic Acids Res 22, 4673-4680. 